\title{
THE TEACHER's PERCEPTION ON LEARNING MEDIA BASED ON LOCAL Resources in Kindergarten in Pontianak City
}

\author{
Desni Yuniarni \\ Universitas Tanjungpura, Pontianak, Indonesia \\ E-mail:yuniarnidesni@yahoo.com
}

\begin{abstract}
The learning media has an important role in a learning activity, especially for early childhood education. Media in learning functions to facilitate the student in a learning activity. Through the media, it will be easier for children to comprehend the material as well as making learning activity becomes more fun. Besides, the using of media in learning will stimulate all the children's development aspect. The Pontianak city itself has many local resources that can be used as learning media in kindergarten. The using of local resources as a learning media, in addition to low cost has many benefits, i.e. introducing the various local resources around the children. By getting to know about those resources, it is hoped that the children will be proud and love their city more. But, the phenomenon in kindergarten is teachers prefer the factory-made learning media even though many more benefits for both teachers and children for using the media from their local resources. Thus, the study aims to find out about the teacher's perception toward learning media that based on local resources in kindergarten in Pontianak city. This is a quantitative descriptive study in a survey form. The sampling method used was purposive sampling. The data was obtained using a questionnaire and interview. Data were then analyzed using quantitative descriptive percentage analysis. The study finding shows that $75 \%$ of kindergarten teachers in Pontianak city agreed that the using of learning media that based on local resources, it is important for early childhood development; total $36 \%$ teachers agreed on the benefits that the students get in using the learning media that based on local resources, while $45 \%$ of teachers did not really agree with using that media in learning activities in kindergarten.
\end{abstract}

Keywords: teacher's perception; local resources-based learning media; kindergarten

\section{INTRODUCTION}

The media has a very important role in the learning process in early childhood education. Through learning media, children are able to directly see the object that relates to the learning materials given by the teacher. The media helps the children to understand more what they have been taught verbally, using visualization in their learning process. Susanti's research (2015) conclude that learning media in kindergarten learning are beneficial to their learning motivation. Moreover, Dewi (2017) state that teaching media is very important to kindergarten learning. Based on two experts, we can sum up that the media has a very important role in the learning process in kindergarten.

According to Khadijah (2016:124) media is an object used to deliver a message from a messenger to other receivers so it can stimulate the early children thoughts, their feelings, attention, as well as interests, so the learning process occurs. From that statement, it can be concluded that the learning media used in kindergarten is a media that can stimulate the early children's development so they can learn and grow up optimally.

The media used in kindergartens learning process is not only factory-made but can also be handmade by the teacher using resources that are found around. The using of learning media based on local resources is not only economical for it is relatively cheaper on its production compared to factorymade media but also may benefit to introduce the children about the unique local resources that can be found around them. By knowing various local natural resources that are typical to their region, the children are expected to be proud and love their county more.

However, many kindergarten teachers in Pontianak city seldom use the local natural resources-based learning media. Hence this study objective, pointed as follows:

1. To find out about the teachers' perception toward the importance of local natural resources-based learning media in a learning activity in kindergarten. 
2. To find out about the teachers' perception of the benefit of the local natural resources-based learning media to stimulate early childhood developmental aspects.

3. To find about the teachers' perception of the problems faced in using the local natural resources-based learning media for early childhood development.

\section{LITERATURE REVIEW}

\section{A. The Definition of Learning Media}

Association for Education and Communication Technology (AECT) (in Dhine, 2007) defined media as an object that can be used in an information delivering process. Education Association (NEA) (Dhine, 2007) defined the media as an object that can be manipulated in a learning process, can be seen, listened, read, and talked.

The media can also function as an instrument in learning activity so it may affect the effectivity of the instructional program. According to Hamalik (2003:202-203) media in learning process is a student learning media that has the ability to center certain parts that are considered important from a unit or an object, to replace the real experience close to a difficult or dangerous object, to homogenize the student's observation aspect, to give information in a moving form, in a process or an activity.

Based on the opinions mentioned above, it can be concluded that a learning media is anything that can be seen, listened, and touched as a tool to facilitate a learning process for early childhood. By using media, the children can comprehend more the learning materials given by the teachers in the class.

Harjanto (2010:43) stated that the media used in a teaching process can be divided into two parts, which are media in narrowed definition and media in a wider definition. Media in narrowed definition can be defined as a media that is used effectively in a more planned learning activity. While media in wider definition means a media that is used in a learning process that is not only as an electronic communication media, but also those such as slides from the computer, photographs, diagrams, and charts made by the teacher. The media that is used in early childhood education is a media that is often handmade by the teacher or factorymade, can be bought but is suited to the related themes.

The learning method in kindergarten is a playing media for children because for children that age, playing is an unseparated part of their daily life, including in the learning process in the school. Through playing activity of the children, the teacher will get an idea about the developmental phase and general ability of the children (Patmodewo, 1995). In other words, through playing, the children can learn and they learn using the games they preferred. Thus, the media has an important role in a learning activity in kindergarten.

\section{B. The Advantage of Using Learning Media for Early Children}

The media in the learning process in kindergarten has an important role in early childhood. With the media in a kindergarten learning activity, the learning experience of the student will be felt more real and fun. The students can directly see the material object given to them. The experience of directly seeing the object in a learning process will ease the student to comprehend more the materials given. The learning media will give positive impact in a child's developments, both those related to the child's brain development and the child's creativity (Hasnidah, 2015:36). The object in a learning media can be in a real object form or can be in a form of the miniature, model, or audiovisual or audial-presented picture (Ahmad, 1997:32).

The media in a real object form in a learning material, for example, when a teacher teaches them about various vegetables that are good for their health, the teacher may bring those vegetables to the class, such as kangkung (kale), spinach, and carrot, so the children can see directly those vegetables. They can observe the real form of those vegetables so they are able to mention the unique feature of each vegetable. By observing directly those vegetables, it will be easier for the children to memorize the advantage of each vegetable. In this occasion, the teacher may also explain the importance of consuming vegetables for human's health for they contain many beneficial elements for their body.

However, not all learning media can be shown to the children in their real form. For example, when teaching them about various transportations; such as the land, sea, and air transportation, the teacher may bring miniature objects of airplane, ship, or car.

The using of media in a learning activity has many advantages (Azhar, 2014), such as:

1. To make the learning process becomes more standardized.

The media given to the students in their learning will give a more concrete and clear explanation about the materials in a learning process. For example, when a teacher teaches about professions, such as a doctor, the teacher will present a picture of a doctor with his/her characterized uniform, which is a white coat and stethoscope hanging in his/her neck. That kind of media will homogenize the students' perception about a figure of a doctor.

2. To make the learning process becomes more interesting. The learning process will draw the students' interest if it's not only given verbally by the teacher but also visually or audiovisually. The interesting media will improve the students' concentration as well as grow the students' curiosity so they will be focused on the material taught by the teacher.

3. More interactive learning process.

The teacher should make the students participate in the learning process' the student should be actively involved in doing the learning activity so there will be a positive interaction between the teacher and the students in the learning process.

4. Shorten the learning time

Media in the learning process will make the learning process becomes more efficient especially in time 
aspect, because the students may directly see an object so the teacher does not need to give a detailed explanation about the object.

5. Improving the learning quality

The learning media may improve the students' understanding of the material given to the learning quality of the students will also improve.

6. The learning process can occur anytime and anywhere By using media in the learning process, the learning activity can be happened without depending on a certain time or place. For example, when the teacher teaches about how the rain happens, the teacher may explain its process using the media without having to wait for the rain or going to a rain place.

7. Improving the positive attitude of the students toward the learning material as well as the learning process.

The learning media can increase the interest and the curiosity of the students toward the learning material. For example, when the teacher teaches about nature's phenomena, volcano eruption, for example, the teacher may provide a learning media that may depict the volcano when it erupts. The media will draw the students' attention toward the material as well as grow the curiosity of the students about several things related to the volcano.

8. The teacher's role becomes more positive

The learning media will make students become more curious about the material, so it will trigger the students to explore the media given, making the teacher is not the only learning source, because from the media the students may find out by themselves things that they want to learn (Pedersen, 2008:20).

\section{The Problems in Using the Learning Media for Early} Children

The using of the media in kindergarten learning has several disadvantages, which are:

1. Each learning media used by kindergarten student still need to be explained by the teacher. A media is only a tool used by the teacher to aid the learning activity that in its use the teacher still needs to explain its name, its function, and how to use it. In this manner, when giving media to the students, the teacher should previously provide an explanation about the media.

2. The preparation and planning should be done efficiently before the media is used to the students' attention will be focused on the media used. The media in the learning process is an aid to achieve the learning goal, so the choice of the media and its utilization should be prepared efficiently to reach the determined learning objective.

3. The media operation using electrical is against the terms and condition of the media for kindergarten students. The media choosing for early children should concern the safety aspect because they are in a phase with high curiosity that they might do something unexpected out of the teacher's control. Thus, it is suggested not to use a high-risk media for children, such as in making a cake in a cooking class if one of the media used is a mixer, electrical equipment to mix the ingredients, the teacher should be the one who uses the tool. However, the students may see how the teacher uses the tool; know the name of the tool and the function of the tool.

4. Most media that does not use electric is the still image, so it tends to bore the kindergarten students. It actually depends on the teacher's creativity, for a still image can also draw the students' attention if the teacher has the ability to make the learning activity interesting, so it would not bore the students.

5. If it presented too long, the students may get bored to follow. The length of early childhood education students is short, urging the teacher to plan the learning process efficiently to achieve the learning objective using the interesting learning media and the students feel fun in the studying process.

6. It needs extra maintenance because the materials used are generally easy to be broken. The teacher should provide guidance to the students on how to use and maintain those media, so both the teacher and students can altogether take care of the media so it lasts longer and does not break easily.

7. The time needed in making a non-electrical media is relatively longer and usually can only be made manually. The disadvantage of the media that is manually made is sometimes it is not neat and less attractive, or less similar to the real object. But, those problems can be solved using the teacher's creativity that the teacher should make the learning process interesting so the students' are not only focused on the media.

Based on the explanation above, it can be concluded that the utilization of a media in the learning process needs special attention of the kindergarten teacher so it can be used optimally.

\section{METHODOLOGY}

Comes from the problems that are studied, the method used in this study was descriptive research that was done using a quantitative survey method. Through the used descriptive method, the author intends to present or describe the teachers' perception toward the using of a playing media that is based on the local natural resources in kindergarten in Pontianak.

\section{A. The Study Form}

Subana (2011:91) stated that the forms of the descriptive method are classified into eight research form. From those eight research form, the author using the survey research form.

According to Darmadi (2011:235), the survey research is quantitative research that uses same structured or systematic questions given to several people and all of the answers are recorded by the researcher, to be processed and analyzed. Those structured questions are of the called 'questionnaire'. The questionnaire consists of questions that wan to be asked to the respondents to measure some variables, the relationship between variables, or about the experience or opinion of the respondents. 


\section{B. The Study Approach}

The study approach used was a quantitative approach. The quantitative research method is, as explained by Sugiyono (2015:14), a study method that is based on a positive philosophy; a method that is used to study a certain population or sample; the sampling technique is often using a certainly suitable calculation; the quantitative/statistic data is obtained in order to test the determined hypothesis and the data in numbers will be analyzed statistically.

Thus, the data in this study is in numbers followed by descriptive elaboration to answer the problems of the study.

\section{The Study Location}

The location determination is intended to ease and clear the location that becomes the target of the study to narrow the problem scope. The location of this study is private/governmental kindergarten in Pontianak city.

\section{Population and Sample}

1) Population

According to Sugiyono (2015:117), "Population is a generalized area that consisted of object/subject with certain characterized quality that is established by the researcher to be studied and furthermore concluded".

Based on the definition, we may conclude that the population is the total of study objects that are presented by the source of the data in a study, which is a person that has a certain character of an object. The data source of this study is:

1. Private and governmental kindergarten in Pontianak city

2. Certified teachers

3. The teacher of the class

4. The undergraduate teachers of early childhood education

Based on those characteristics, the data obtained as the population in this study was 385 kindergarten teachers in Pontianak city that met the criteria determined by the author, including the undergraduate of early childhood education as well as a certified kindergarten teacher.

2) Sample

According to Sugiyono (2015:118) "Sample is the part of the total and characteristic of the population." In this study, the author used sampling purposive method to obtain the sample, which is the sample that is contacted is matched with certain determined criteria based on the study objective.

The criteria for choosing the sample using purposive sampling in this study are:

1. The teacher of private and governmental kindergarten in Pontianak city

2. The teacher that is taken as the sample is the undergraduate of early childhood education.

3. Certified teachers

4. Teachers that teach in class, not the headmaster or teachers of other fields
Even when the sample criteria were clearly set, the total of the sample was still big. Because of the limited time, from total 385 certified undergraduates of early childhood education kindergarten teachers, the author only took $18 \%$ of the total sample obtained, which is $69.3 \%$ or rounded into 69 certified undergraduates of early childhood education kindergarten teachers.

\section{E. The Data Obtaining Technique and Tools}

To obtain the data related to the problems studied, a suitable technique and tool are needed that is suitable to the study objective. Information needed to describe something or events should be contained in the data. It means, to get such information we should use data obtaining techniques so the information will be easily retrieved. According to Arikunto (2013), there are five data obtaining techniques. Based on those statements, in this study, the technique used was the questionnaire and interview.

\section{F. The Instrument of Validity and Reliability Test}

\section{1) The Instrument of Validity Test}

To test the validity, the author used constructed validity. Constructed validity may use expert judgments. After the instrument is constructed based on the aspects measured based on certain theories, it will be assessed by the expert. The expert will judge or asses the constructed instrument. Only the questionnaire that fulfills the terms and condition can be used as a data obtaining tool.

2) The Instrument of the Reliability Test

The reliability test of the instrument used in this study was the Rasch method. The reliability value highly depends on the sample characteristic. The Rasch model is one of the approaches that can be used to estimate the reliability that is freed from the sample characteristic (Sumintono dan Widhiarso, 2014).

\section{G. Data Analysis Technique}

The data analysis technique is a process of finding and arranging the data obtained from the interview, field note, and other sources systematically so it is easier to understand and the finding can be informed to other people (Sugiyono, 2015: 244 ). Based on that definition by the experts, the data analysis technique is a process of organizing and sorting a data into patterns, categories, a basic description unit so it can be concluded into a theme and can be formulated based on the data. The data analysis technique used in this study was quantitative descriptive without general conclusion.

Furthermore, to determine the data analysis we calculated the relative percentage using this formula (Sudijono, 2013):

$$
P=\frac{f}{N} \times 100 \%
$$

Note:

$f=$ The searched frequency

$N=$ Number of cases

$P=$ Percentage number 


\section{RESULT AND DISCUSSION}

From the questionnaire findings, we can conclude as presented in Fig. 1.

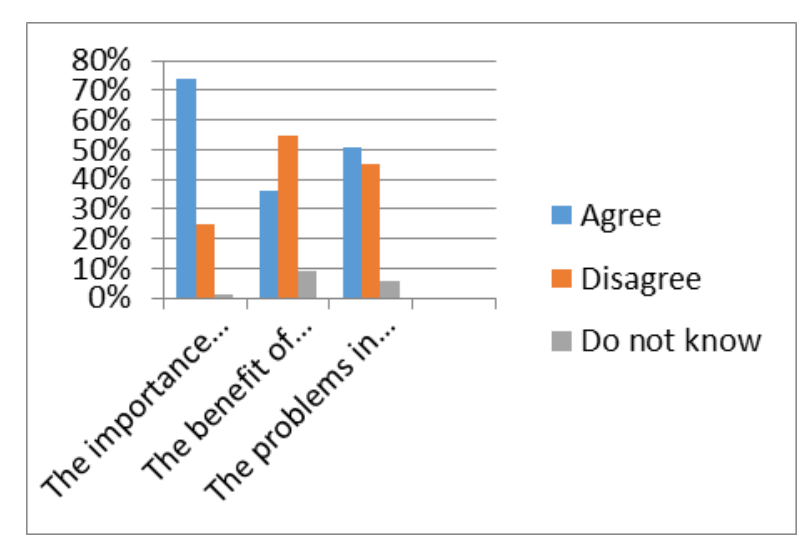

Fig. 1 The percentage of teachers' perception of learning media that based on local natural resources

Based on the diagram above, we can conclude that $75 \%$ of teachers of the kindergarten teacher in Pontianak city agreed that the learning media that based on the local natural resources is important for the early childhood development. The interview findings show that the media is important to be presented in a learning process in kindergarten so the students get to know the local natural resources of their region. By knowing various natural media, the students will grow interested in learning because the natural media is a media that is seldom used in the learning activity in kindergarten. The unique feature of the media drew the interest and curiosity of the students to find out further about the media. The media based on the local resources that have been used in the kindergarten learning activity was banana midrib. The banana midrib can be used for stamping in a kindergarten learning activity. By using the banana midrib, the teacher may teach about the characteristic of a banana tree, how it grows and the benefit of a banana tree.

Total 36\% of teachers of kindergarten in Pontianak city agreed on the benefit that the students get in using the learning media using local natural resources. The interview result stated that they believe by using such media, they can stimulate all early childhood developmental aspects. The stimulation of the developmental aspect can be done by making a game from those media. For example, by using banana midrib, the teacher does not only tell about the banana trees but can also use its leaves to weave, to stimulate the children's fine motor developmental aspect. The banana leaves weaving can further be colored using food coloring so it may stimulate the children's art developmental aspect.

However, there are some problems in practicing the learning activity using those local natural resources. Total $51 \%$ kindergarten teachers in Pontianak city stated that the problems that often faced in using such media are, for example, those related to the preparation needed in preparing those media before giving them to children. The natural resources such as banana midrib should be cleaned or removed from its sap. Thus, a total of $45 \%$ teacher did not agree with using such media in a kindergarten learning activity.

\section{CONCLUSION AND SUGgestion}

\section{A. Conclusion}

Based on the questionnaire and interview calculation on the teachers' perception toward the learning media that is based on the local natural resources, it can be concluded as follows:

1. The kindergarten teachers in Pontianak city have a good perception about the importance of learning media that is based on local natural resources for learning process in kindergarten.

2. The kindergarten teachers in Pontianak city have a fairly good perception about the benefit of learning media that is based on local natural resources to stimulate the development aspects of early childhood.

3. The kindergarten teachers in Pontianak city have a fairly good perception of the problems faced in practicing the utilization of learning media that is based on local natural resources for early childhood development

\section{B. Suggestion}

Regarding the conclusion of this study that is presented above, here are several suggestions related to the conclusion:

1. The problems faced in practicing the learning activity using learning media that is based on local natural resources in Pontianak city can be reduced by improving the teacher's understanding in utilizing those media as a learning media in kindergarten. By improving their understanding, they are expected to be more motivated and more creative in preparing the natural resources as a learning method in their kindergarten, to minimize the problems they would face in using such media.

2. To introduce local natural resources to kindergarten students in Pontianak city, it is suggested to hold a various competition to create a learning media for the teachers, so they can be more motivated and more creative in using those natural resources for learning activities in their kindergarten.

3. The early children can participate in competitions that use the natural-based game to grow their interest in natural resources around them

\section{REFERENCES}

Ahmad, Rohani. (1997). Media Instruksional Edukatif. Jakarta: PT RinekaCipta.

Arikunto, S. (2013). Prosedur Penelitian: Suatu Pendekatan Praktik. Jakarta: Rineka Cipta.

Azhar, Arsyad. (2014). Media Pembelajaran. Jakarta: Raja Grafindo Persada.

Darmadi, Hamid. (2011). Metode Penelitian Pendidikan. Bandung: Alfabeta 
Dewi, Kurnia. (2017). Pentingnya Media Pembelajaran untuk Anak Usia Dini. Jurnal Pendidikan Islam Anak Usia Dini: Raudhatul Athfal, 1(1). http://jurnal.radenfatah.ac.id/index.php/raudhatulathfa 1/article/view/1489

Dhine, Nurbiana. (2007). Metode Pengembangan Bahasa. Jakarta: Universitas Terbuka.

Hamalik, Oemar. (2003). Proses Belajar Mengajar. Jakarta: PT. Bumi Aksara.

Harjanto. (2010). Perencanaan Pengajaran. Jakarta: Rineka Cipta.

Hasnidah. (2015). Media Pembelajaran Kreatif. Jakarta: Luxima Metro Media.

Khadijah. (2016). Pengembangan Kognitif Anak Usia Dini. Medan: Perdana Publishing.

Patmodewo, S. (1995). Pendidikan Anak Pra Sekolah. Jakarta: Rineka Cipta

Pedersen, Paul. (2008). Menjadi Guru Inisiator. Semarang: Rasail.

Subana, M. Sudrajat. (2011). Dasar-Dasar Penelitian Ilmiah. Bandung: Pustaka Setia.

Sudijono, Anas. (2013). Pengantar Evaluasi pendidikan. Jakarta: PT Raja Grafindo Persada.

Sugiyono. (2015). Metode Penelitian Kuantitatif Kualitatif dan $R \& D$. Alfabeta: Bandung.

Sumintono, Bambang and Widhiarso, Wahyu. (2014). Aplikasi Model Rasch untuk Penelitian Ilmu-ilmu Sosial. Trim Komunikata.

Susanti, Marlin Dwi. (2015). Pemanfaatan Media Pembelajaran Terhadap Motivasi Belajar Anak TK. Jurnal Pendidikan Anak, 4. Edisi 2. https://journal.uny.ac.id/index.php/jpa/article/downlo $\mathrm{ad} / 12358 / 8928$ 